\title{
ORIGINALARTICLE Preliminary stages of cross-cultural adaptation of the Brazilian Portuguese version of McMaster Family Assessment Device
}

\author{
Estágios preliminares da adaptação transcultural da versão \\ brasileira do McMaster Family Assessment Device
}

Eliane Traebert', Karoliny dos Santos', Luciana Müller Carvalho², Jane da Silva', Jefferson Traebert

\section{Keywords}

Family relations, validation studies, translations, Brazil.

\begin{abstract}
Objective: To carry out the preliminary stages of the cross-cultural adaptation of the Family Assessment Device (FAD) to Brazilian Portuguese language and examine its reliability. Methods: The translation and cross-cultural adaptation of the FAD were developed according to the methods internationally recommended. The resulting product was applied to 80 individuals who completed the questionnaire on two different occasions, seven days apart. Internal consistency was obtained through Cronbach's alpha, and reliability was estimated by using the Bland and Altman method. Results: The internal consistency obtained was very good (Cronbach's alpha $=0.910$ ). The mean differences of FAD dimensions found in the Bland and Altman test were the following: - 0.21 (Problem Solving); -0.32 (Communication); -0.17 (Roles); 0.2 (Affective Responsiveness); -0.27 (Affective Involvement); -0.08 (Behavior Control); -0.02 (General Functioning). Conclusion: The processes of translation and cross-cultural adaptation were successful. Assessment of the structural validity and external construct validity is recommended for the improvement of the Brazilian version.
\end{abstract}

\section{RESUMO}

Objetivo: Proceder as fases preliminares da adaptação transcultural do Family Assessment Device (FAD) para o português falado no Brasil e analisar sua confiabilidade. Métodos: A tradução e a adaptação transcultural do FAD foram realizadas de acordo com métodos internacionalmente recomendados. A versão brasileira foi aplicada em 80 indivíduos que completaram o questionário em duas ocasiões distintas, com intervalo de sete dias. A consistência interna foi avaliada pelo alfa de Cronbach e a reprodutibilidade foi estimada utilizando o método de Bland-Altman. Resultados: A consistência interna obtida foi muito boa (alfa de Cronbach $=0,910$ ). A média das diferenças das dimensões do FAD encontradas no teste de Bland-Altman foi a seguinte: -0,21 (Resolução de Problemas); -0,32 (Comunicação); -0,17 (Papéis); 0,2 (Resposta Afetiva); -0,27 (Envolvimento Afetivo); -0,08 (Controle do Comportamento); -0,02 (Funcionamento Geral). Conclusão: Os processos de tradução e adaptação transcultural foram bem-sucedidos. A aferição da validade de conteúdo é recomendada para o aprimoramento da versão proposta.

1 University of Southern Santa Catarina at Palhoça, Postgraduate Program in Health Sciences.

2 University of Southern Santa Catarina at Palhoça, School of Medicine.

Received in

Approved in

Approved in

Address for correspondence: Jefferson Traebert

Av. Pedra Branca, 25

Cidade Universitária Pedra Branca

88137-270 - Palhoça, SC, Brazil

E-mail: jefferson.traebert@gmail.com

Telephone: (+55 48) 3279-1167

Fax: (+55 48) 3621-3363 


\section{INTRODUCTION}

Family functioning studies have raised great interest in the literature given that they identify the dynamics and influence of psychosocial variables on the detection of both general diseases and psychiatric disorders'. Family comprises a complex system to be assessed because each has a peculiar way of life, deeply influenced by cultural factors ${ }^{2}$.

The need for understanding intra-family relationships led to the creation of a variety of tools to assess them, with different goals ${ }^{3}$. One of these tools is the McMaster Approach to Families, proposed by Epstein et al. in $1983^{4}$, which is a model for family assessment and treatment. It encompasses a multidimensional theory, measuring tools to address constructs, and a well-defined method of family therapy 5 .

The assessment model is based on the following key assumptions: (a) all family parts are interrelated, and one part of the family cannot be understood in isolation from the rest of the system; (b) family functioning cannot be understood based on each member in isolation from the rest of the family group; (c) the family's structure and organization are important factors that determine the behavior of family members; (d) behavior of family members is shaped by family transaction patterns ${ }^{5}$.

The authors of the McMaster Approach to Families propose six dimensions to express such assumptions, and a general functioning dimension. ${ }^{4}$ The first dimension is "Problem Solving", which assesses the family's ability to resolve problems at a level that maintains effective family functioning. The second dimension is "Communication", which focus on whether verbal messages between family members are clear and direct. The third dimension refers to "Roles" of the family regarding organized patterns of behavior to facilitate family life, including the distribution of tasks to be performed responsibly. The fourth dimension, "Affective Responsiveness", assesses the extent to which individual family members express affection over a range of different stimuli. The fifth dimension is "Affective Involvement", which measures the extent to which family members are interested in and place value on each other's concerns. The sixth dimension is "Behavior Control", which assesses the way in which a family maintains standards for the behavior of its members within the family system. The seventh dimension is "General Functioning", which assesses the overall health/ pathology of the family.

The necessary tools for the measurement of family functioning based on the proposed model include a selfadministered questionnaire named Family Assessment Device (FAD), a scale to be filled out by a family therapist, known as the McMaster Clinical Rating Scale and a structured script for family interview called McMaster Structured Interview for Family Functioning ${ }^{5}$.
The FAD describes the organizational and structural properties of the family according to the perceptions of their own members ${ }^{4}$. It consists of assertions that describe the various aspects of family functioning. The respondent points out how much each situation describes his or her family by selecting one of four alternative responses: strongly agree (1), agree (2), disagree (3), and strongly disagree (4). The FAD scores of each dimension are calculated by summing the responses for each subscale and dividing the sum by the number of assertions. For each dimension, the scores range from 1 (best functioning) to 4 (worst functioning). The questionnaire is supposed to be answered by all family members above 12 years of age, and it takes approximately fifteen to twenty minutes to complete 4 .

The FAD was originally created in the United States of America, and was translated into several languages with cross-cultural adaptation for many countries ${ }^{1,3,6-18}$. Because the FAD is self-administered and can potentially be used in epidemiological population-based studies and due to the lack of a Brazilian Portuguese version, the purpose of this study was to provide a translation into Portuguese and a cross-cultural adaptation for the Brazilian culture. The study was also aimed at discussing the psychometric properties of the proposed version.

\section{METHODS}

This was a cross-sectional study of a Brazilian version proposal of the FAD as a self-administered survey tool. Convenience and non-probability sampling was used to get a community sample.

The study was approved by the Research Ethics Committee of the University of Southern Santa Catarina (CAAE 38240114.0.0000.5369). Guidelines for this study were those recommended by Beaton et al..$^{19}$ and Wild et al. ${ }^{20}$, as described in the following stages:

Stage 1 (initial translation into the target language): The questionnaire was translated from its original English into Brazilian Portuguese by two translators who had no previous involvement in this study. One was a native speaker of English and knew Portuguese as well. The other was a Brazilian who was fluent in English and taught that language.

Stage 2 (synthesis of the translated versions): The two translated versions were compared and synthesized by the authors of the research into a third version.

Stage 3 (back-translation): The synthesized version was back-translated by a native speaker of English, a language teacher with any involvement with the health area and naïve to the original tool.

Stage 4 (expert committee): A committee of experts reviewed the idiomatic, semantic, cultural and conceptual equivalences between the source and target version. It was 
composed of the researchers involved in the study plus a PhD in Nursing. The prefinal version was completed after a discussion by the expert committee on the identified discrepancies.

Stage 5 (test of the prefinal version): The prefinal version of the questionnaire was administered to 10 subjects. After pretesting, adjustments were made on two items to facilitate understanding of the assertion, without changing the basic meaning though. In question 6, "você não consegue dizer como a pessoa está se sentindo", the word "dizer" (tell) was replaced by "saber" (know). In question 37, "temos regras sobre bater em pessoas" (we have rules about hitting people) the statement was rephrased as follows: "temos regras sobre bater ou não bater em pessoas". After incorporating the changes, the researchers approved it as the final version.

Stage 6 (evaluation of the psychometric properties of the final version): Reliability of the Brazilian version was assessed through internal consistency and reproducibility analyses. The sampled subjects completed the questionnaires on two different occasions, seven days apart.

\section{Statistical analysis}

Analysis of the degree of internal consistency of the Brazilian version of the FAD was performed using the standard Cronbach's alpha coefficient. In addition, the value of the Cronbach's alpha was calculated for each dimension and question in case any would have to be excluded from the FAD. The Spearman correlation coefficient was used to evaluate the correlation between individual questions and the results of FAD dimensions. Reproducibility was analyzed by the method proposed by Bland and Altman ${ }^{21}$. Analyses were performed using the Statistical Package for Social Sciences software version 18.0 (SPSS for Windows 18 Chicago, IL, USA).

\section{RESULTS}

The study included 80 subjects with a mean age of 33.9 \pm 12.8 years (amplitude $=49$ ). Among the participants, 42 (52.5\%) were female and the mean education level was 14.1 \pm 4.12 years of educational attainment (amplitude $=19$ ).

Internal consistency assessment for the overall score of the Brazilian version of the FAD showed a Cronbach's alpha of 0.910. The scores on each dimension are shown in Table 1. Cronbach's alpha value was also calculated by excluding each dimension in order to numerically check a trend in responses within each of the seven dimensions of the questionnaire. The same procedure was conducted in each dimension by excluding each of the questions consecutively. Table 2 shows these results, along with the correlations between each question and the overall score of FAD, and between each item and their respective dimensions.

Figure 1 shows a reproducibility analysis between the scores from the FAD questionnaire administered on two different occasions, following the Bland-Altman method. In general, there was a good correlation between the answers, given that the graphs showed mean differences (or bias) close to zero.

Table 1. Internal consistency of the Brazilian version of the FAD

\begin{tabular}{lcc}
\hline FAD & Cronbach's alpha & Cronbach's alpha if the dimension is disregarded \\
\hline Overall analysis & 0.910 & - \\
Dimension 1 - Problem solving (5 items) & 0.692 & 0.911 \\
Dimension 2 - Communication (6 items) & 0.631 & 0.902 \\
Dimension 3 - Roles (8 items) & 0.438 & 0.915 \\
Dimension 4- Affective responsiveness (6 items) & 0.832 & 0.892 \\
Dimension 5 - Affective involvement (7 items) & 0.791 & 0.892 \\
Dimension 6- Behavior control (9 items) & 0.750 & 0.909 \\
Dimension 7 - General functioning (12 items) & 0.877 & 0.869 \\
\hline
\end{tabular}

Table 2. Correlation coefficients ( $r$ ) between the questions and the overall result of the Brazilian version of the FAD, and Cronbach's alpha when the questions were disregarded

\begin{tabular}{|c|c|c|c|}
\hline Questions & $\begin{array}{l}\text { Correlation between } \\
\text { the question and overall } \\
\text { results }\end{array}$ & $\begin{array}{l}\text { Correlation between the } \\
\text { question and result of the } \\
\text { dimension }\end{array}$ & $\begin{array}{c}\text { Cronbach's alpha if } \\
\text { the dimension was } \\
\text { disregarded }\end{array}$ \\
\hline \multicolumn{4}{|l|}{ Dimension 1 - Problem Solving (Resolução de Problemas) } \\
\hline 1- Costumamos agir de acordo com as decisões que tomamos em relação a problema & 0.378 & 0.723 & 0.603 \\
\hline 2- Depois que nossa família tenta resolver um problema, nós geralmente discutimos se funcionou ou não & 0.321 & 0.651 & 0.657 \\
\hline 3- Resolvemos a maioria dos conflitos emocionais que surgem & 0.420 & 0.689 & 0.625 \\
\hline 4- Enfrentamos problemas que envolvem sentimentos & 0.159 & 0.519 & 0.694 \\
\hline 5- Tentamos pensar em diferentes maneiras para resolver os problemas & 0.322 & 0.700 & 0.631 \\
\hline
\end{tabular}




\begin{tabular}{|c|c|c|c|}
\hline Questions & $\begin{array}{l}\text { Correlation between } \\
\text { the question and overall } \\
\text { results }\end{array}$ & $\begin{array}{l}\text { Correlation between the } \\
\text { question and result of the } \\
\text { dimension }\end{array}$ & $\begin{array}{c}\text { Cronbach's alpha if } \\
\text { the dimension was } \\
\text { disregarded }\end{array}$ \\
\hline \multicolumn{4}{|l|}{ Dimension 2 - Communication (Comunicação) } \\
\hline 6- Quando alguém está chateado, os outros sabem o motivo & 0.294 & 0.687 & 0.522 \\
\hline 7- Você não consegue saber como uma pessoa está se sentindo com base no que ela fala & 0.320 & 0.549 & 0.583 \\
\hline 8- As pessoas falam abertamente as coisas em vez de insinuá-las & 0.262 & 0.558 & 0.611 \\
\hline 9- Somos francos uns com os outros & 0.612 & 0.669 & 0.556 \\
\hline 10- Não falamos uns com os outros quando estamos com raiva & 0.303 & 0.457 & 0.633 \\
\hline 11- Quando não gostamos do que alguém fez, nós dizemos diretamente & 0.425 & 0.539 & 0.612 \\
\hline \multicolumn{4}{|l|}{ Dimension 3 - Roles (Papéis) } \\
\hline 12- Quando você pede que alguém faça algo, você precisa verificar se realmente ofez & 0.189 & 0.455 & 0.423 \\
\hline 13- Nós nos certificamos de que cada membro da família cumpra suas responsabilidades & 0.101 & 0.306 & 0.434 \\
\hline 14- As tarefas familiares não são distribuídas de maneira igual & 0.215 & 0.564 & 0.363 \\
\hline 15- Temos dificuldade em pagar nossas contas & 0.139 & 0.264 & 0.504 \\
\hline 16- Temos pouco tempo para analisar interesses pessoais & 0.262 & 0.468 & 0.345 \\
\hline 17- Conversamos para ver quem deve fazer os trabalhos domésticos & 0.495 & 0.503 & 0.372 \\
\hline 18- Quando pedimos às pessoas que façam alguma coisa, precisamos ficar lembrando para que elas façam & 0.250 & 0.541 & 0.344 \\
\hline 19- Em geral não ficamos satisfeitos com as tarefas familiares que nos são atribuídas & 0.343 & 0.354 & 0.428 \\
\hline \multicolumn{4}{|l|}{ Dimension 4 - Affective Responsiveness (Resposta Afetiva) } \\
\hline 20- Temos dificuldade em demonstrar nosso afeto um pelo outro & 0.581 & 0.756 & 0.798 \\
\hline 21- Alguns de nós não se manifestam emocionalmente & 0.482 & 0.712 & 0.811 \\
\hline 22- Não demonstramos o nosso amor uns pelos outros & 0.456 & 0.705 & 0.798 \\
\hline 23- 0 carinho fica em segundo plano em nossa família & 0.527 & 0.692 & 0.795 \\
\hline 24- Expressamos nosso carinho & 0.660 & 0.731 & 0.810 \\
\hline 25-Choramos abertamente & 0.399 & 0.687 & 0.817 \\
\hline \multicolumn{4}{|l|}{ Dimension 5 - Affective Involvement (Envolvimento Afetivo) } \\
\hline 26- Se alguém está com problemas, os outros se envolvem muito & 0.460 & 0.432 & 0.826 \\
\hline 27- Você só consegue a atenção dos outros quando é importante para eles & 0.544 & 0.653 & 0.756 \\
\hline 28- Somos muito egoístas & 0.420 & 0.690 & 0.764 \\
\hline 29- Apenas nos envolvemos uns com os outros quando alguma coisa nos interessa & 0.521 & 0.793 & 0.727 \\
\hline 30- Demonstramos interesse para com os outros quando podemos tirar algum proveito pessoal & 0.515 & 0.820 & 0.731 \\
\hline 31- Nossa família demonstra interesse para com os outros somente quando pode tirar algum proveito & 0.531 & 0.795 & 0.744 \\
\hline 32- Ainda que a intenção seja boa, nós nos intrometemos demais na vida uns dos outros & 0.458 & 0.617 & 0.775 \\
\hline \multicolumn{4}{|l|}{ Dimension 6 - Behavior Control (Controle do Comportamento) } \\
\hline 33- Não sabemos o que fazer quando surge uma emergência & 0.330 & 0.524 & 0.731 \\
\hline 34- Você não é punido quando quebra regras & 0.367 & 0.493 & 0.737 \\
\hline 35- Sabemos o que fazer em caso de emergência & 0.505 & 0.541 & 0.729 \\
\hline 36- Não temos regras claras sobre os hábitos de higiene & 0.329 & 0.670 & 0.702 \\
\hline 37- Temos regras sobre bater ou não bater em pessoas & 0.276 & 0.560 & 0.756 \\
\hline 38- Não obedecemos às regras ou normas & 0.330 & 0.586 & 0.719 \\
\hline 39- Se as regras são quebradas, não sabemos 0 que vai acontecer & 0.359 & 0.497 & 0.735 \\
\hline 40-É possível se comportar de qualquer maneira em nossa família & 0.388 & 0.689 & 0.704 \\
\hline 41- Temos regras sobre situações perigosas & 0.476 & 0.631 & 0.725 \\
\hline \multicolumn{4}{|l|}{ Dimension 7 - General Functioning (Funcionamento Geral) } \\
\hline 42-É difícil planejar atividades familiares porque não nos entendemos & 0.527 & 0.658 & 0.868 \\
\hline 43-Em momentos difíceis, podemos recorrer ao outro em busca de apoio & 0.628 & 0.789 & 0.855 \\
\hline 44- Não podemos falar uns com os outros sobre a tristeza que sentimos & 0.513 & 0.739 & 0.858 \\
\hline
\end{tabular}




\begin{tabular}{|c|c|c|c|}
\hline Questions & $\begin{array}{l}\text { Correlation between } \\
\text { the question and overall } \\
\text { results }\end{array}$ & $\begin{array}{l}\text { Correlation between the } \\
\text { question and result of the } \\
\text { dimension }\end{array}$ & $\begin{array}{c}\text { Cronbach's alpha if } \\
\text { the dimension was } \\
\text { disregarded }\end{array}$ \\
\hline 45- As pessoas são aceitas pelo que são & 0.437 & 0.555 & 0.877 \\
\hline 46- Evitamos discutir sobre nossos medos e preocupações & 0.494 & 0.513 & 0.874 \\
\hline 47- Evitamos discutir sobre nossos medos e preocupações & 0.626 & 0.731 & 0.858 \\
\hline 48- Há muitos sentimentos ruins na família & 0.404 & 0.569 & 0.867 \\
\hline 49- Nós nos sentimos aceitos por aquilo que somos & 0.544 & 0.585 & 0.874 \\
\hline 50- Tomar decisões é um problema para a nossa família & 0.571 & 0.600 & 0.870 \\
\hline 51-Somos capazes de tomar decisões sobre como resolver problemas & 0.534 & 0.642 & 0.866 \\
\hline 52- Não nos damos muito bem juntos & 0.545 & 0.670 & 0.871 \\
\hline 53- Temos confiança uns nos outros & 0.540 & 0.634 & 0.868 \\
\hline
\end{tabular}
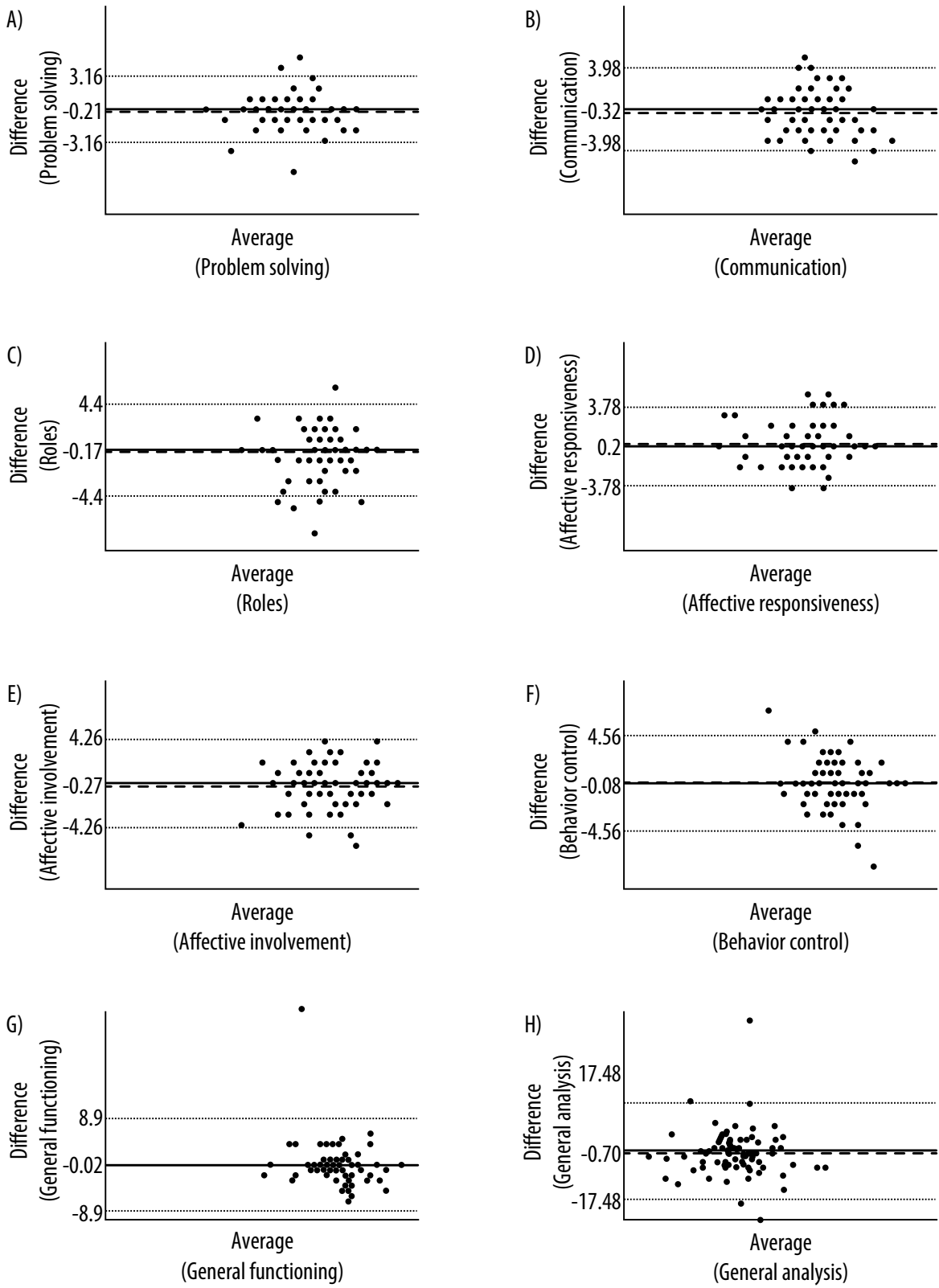

Figure 1. Graphical representation of the FAD reproducibility according to the Bland-Altman method. Dotted lines [......] represent \pm 2 SD. (A) Problem Solving; (B) Communication; (C) Roles; (D) Affective Responsiveness; (E) Affective Involvement; (F) Behavior Control; (G) General Functioning; (H) General Analysis of the questionnaire. 


\section{DISCUSSION}

In general, the results shown that the internal consistency obtained was very good. The process of cultural adaptation was conducted in accordance with international standards ${ }^{19,20}$. Similarly to what was done in the original validation study, this research used a sample of young, healthy individuals. Therefore, the psychometric properties of the Brazilian version of the FAD are derived from a non-clinical sample. Consequently, internal consistency and reliability need to be considered in the context of the scores obtained for the original questionnaire and other language versions of the same sample type.

The central question of this research refers to the internal consistency of the proposed version, especially if the scores obtained in the Brazilian version are similar to those shown in the original questionnaire and other studies in different languages. The Brazilian version showed a high internal consistency (Cronbach's alpha $=0.910$ ), which is similar to those found in other versions ${ }^{1,8,22,23}$. With regard to the internal consistency of the FAD dimensions, the Brazilian version showed similar scores to those found in studies using comparable samples. The exceptions were "Communication" and "Roles" dimensions, which showed a Cronbach's alpha of 0.63 and 0.43 , respectively, in this study. A comparative table of Cronbach's alpha values for different versions that used non-clinical samples is shown in Table 3.

Rationale for a smaller internal consistency of the "Roles" dimension can be hypothesized. It is important to note the questions that showed lower correlation with the overall results of the dimension: questions $15(r=0.264), 13(r=0.306)$, and $19(r=0.354)$. These questions are related to individual responsibility and satisfaction that refer to very complex constructs requiring analysis based on well-designed studies for a good understanding, possibly qualitative in nature. Question 15, related to financial difficulties in paying the family bills, showed the lowest correlation index. This may reflect typical ambiguities of economic crises and political troubles the country has been undergoing in recent years.
However, it is important to consider that even showing a low internal consistency, its impact on the overall score was minimal. If that dimension were removed from the questionnaire, the internal consistency scores would only be affected in the third decimal place, changing the Cronbach's alpha value from 0.910 to 0.915 (Table 1).

In this study, the "Communication" dimension also had a smaller internal consistency. This dimension defines how information is exchanged within a family, with focus on verbal exchange. The aim of this dimension is assess the clarity with which the content of the information is exchanged. "Communication" considers whether the message is clearly directed to the person for whom it is intended ${ }^{5}$. It is possible that the low internal consistency found in this item is related to difficulty of the sample to target and clearly express the feelings. This can be attributed to the short period of the members of family to spend time together, since in most homes the members spend much of their time with work to prove their livelihood.

Low correlation coefficients were observed between individual questions and the overall result of the questionnaire, particularly in dimensions such as "Problem Solving", for example, in Question 4 ( $r=0.159)$; "Communication", in Question $6(r=0.294)$ and Question 8 $(r=0.262)$; "Roles", in Question $13(r=0.101)$ and Question $15(r=0.139)$; and "Behavior Control", in Questions 33 and $38(r=0.330)$. These figures indicate that the analysis within each dimension could bring more valuable information than the analysis of the overall scores from the questionnaire, given that the correlations between each question and the overall result of the dimension to which they belonged were generally higher.

Finally, the test-retest reproducibility analysis showed good agreement, given that in the Bland-Altman's graph representation mean differences were close to zero. Nevertheless, some outliers were observed in all dimensions and in the overall analysis of the questionnaire. Of all the FAD dimensions, "Problem Solving" (Figure 1A) showed the highest reproducibility for presenting the lowest average

Table 3. Internal consistency scores of FAD versions of studies using non-clinical samples

\begin{tabular}{lcccccccc}
\hline Version & Sample & PS & C & R & AR & Al & BC & GF \\
\hline Original (Epstein et al., 1983) & 294 & 0.74 & 0.75 & 0.72 & 0.83 & 0.78 & 0.72 & 0.92 \\
Italian (Roncone et al., 1998) & 110 & 0.77 & 0.72 & 0.56 & 0.72 & 0.59 & 0.53 & 0.79 \\
Icelandic (Kazarian, 2010) & 240 & 0.76 & 0.79 & 0.69 & 0.73 & 0.73 & 0.70 & 0.86 \\
Dutch (Wenninger et al., 1993) & 233 & 0.73 & 0.79 & 0.66 & 0.81 & 0.70 & 0.70 & 0.89 \\
Chinese (Shek, 2002) & 451 & 0.70 & 0.62 & 0.57 & 0.56 & 0.60 & 0.56 & - \\
American (Kabacoff, Miller, Bishop, Epstein, \& Keitner, 1990) & 627 & 0.74 & 0.70 & 0.70 & 0.57 & 0.73 & 0.76 & 0.70 \\
French (Speranza et al., 2012) & 115 & 0.70 & 0.80 & 0.67 & 0.69 & 0.78 & 0.74 & 0.85 \\
Brazilian (this study) & 80 & 0.69 & 0.63 & 0.43 & 0.83 & 0.79 & 0.75 & 0.87 \\
\hline
\end{tabular}

PS: Problem Solving; C: Communication; R: Roles; AR: Affective Responsiveness; Al: Affective Involvement; BC: Behavior Control; GF: General Functioning. 
difference between the responses and the lowest standard deviation. On the other hand, the "General Functioning" dimension, despite having a small mean difference, showed a high standard deviation, revealing a wide variety of answers. Although the average difference in the overall analysis of FAD was small (Figure $1 \mathrm{H}$ ), the standard deviation was high, probably as a result of the heterogeneity of different dimensions.

To the best of our knowledge, this study represents the first effort to provide an important tool, developed in another language and another culture, to be used in the Brazilian Portuguese. Despite being a preliminary study, the main limitations presented here can serve for future studies to validate the FAD in Brazil. The limitations include the small sample size as compared to that of other validation studies, the solely use of non-clinical samples, and homogeneous socio-demographic characteristics of the participants. However, in proposing a Dutch version, Wenninger et al. have shown that the FAD scores were not significantly affected by gender, age, and religion of the participants ${ }^{6}$.

Some limitations must be considered. First, the limited sample size may have reduced the statistical power of the analysis. However, the sample size of our study was similar to others found in the literature. Second, the Brazilian version was not applied in a clinical sample. Nevertheless, the psychometric properties tested are derived from a homogenous non-clinical sample. Even though family's structure are different between countries and even within a country itself, it seems that the inconsistencies may be related to problems detected in the original FAD structure. The options on the intensity of the response, such as "agree" and "strongly agree" meanly a similar condition and hypothetically could be affected by time and the life situation in which the family member is.

Despite being a preliminary study, we have demonstrated regular psychometric properties for a Brazilian version of the FAD. The results indicated difficulties that mirror a complex theoretical model related to psychosocial aspects of family functioning. Improvement of the proposed Brazilian version of the FAD could represent an important step towards a better understanding of family functioning, and therefore, provide an alternative to valid research that incorporates the family organization and functioning as an explanatory basis for several health outcomes. Thereby, we can recommend the use of the Brazilian version in larger studies that aim to establish measurement equivalence, such as construct validity and dimensional structure.

\section{INDIVIDUAL CONTRIBUTIONS}

Eliane Traebert - Contributed to conception, design, analysis and interpretation of data; contributed substantially to drafting the article; given the final approval of the version to be published.

Karoliny dos Santos - Contributed to conception, design, analysis and interpretation of data; contributed substantially to drafting the article; given the final approval of the version to be published.

Luciana Müller Carvalho - Contributed to conception, design, analysis and interpretation of data; contributed substantially to drafting the article; given the final approval of the version to be published.

Jane da Silva - Contributed to conception, design, analysis and interpretation of data; contributed substantially to drafting the article and revising it critically for important intellectual content; given the final approval of the version to be published.

Jefferson Traebert - Contributed to conception, design, analysis and interpretation of data; contributed substantially to drafting the article and revising it critically for important intellectual content; given the final approval of the version to be published.

\section{CONFLICTS OF INTEREST}

The authors declare that there are no conflicts of interest.

\section{ACKNOWLEDGEMENT}

We thank Prosup/Capes, Brazil for granting doctoral scholarships to the authors of this study, Eliane Traebert and Karoliny dos Santos. We also thank Dr. Nazaré Otília Nazário, of the University of Southern of Santa Catarina, Brazil, for her contributions to this study.

\section{REFERENCES}

1. Barroilhet S, Cano-Prous A, Cervera-Enguix S, Forjaz MJ, Guillen-Grima F. A Spanish version of the Family Assessment Device. Soc Psychiatry Psychiatr Epidemiol. 2009;44:1051-65.

2. Juliusdottir GM, Olafsdottir H. An Icelandic Version of McMasters Family Assessment Device (FAD). Res Social Work Prac. 2014:1-13.

3. Roncone R, Rossi L, Muiere E, Impallomeni M, Matteucci M, Giacomelli R, et al. The Italian version of the Family Assessment Device. Soc Psychiatry Psychiatr Epidemiol. 1998;33:451-61.

4. Epstein NB, Baldwin LM, Bishop DS. The McMaster Family Assessment Device. J Marital Fam Ther. 1983;9:171-80.

5. Miller IW, Ryan CE, Keitner GI, Bishop DS, Epstein NB. The McMaster Approach to Families: theory, assessment, treatment and research. J Fam Ther. 2000;22:168-89.

6. Wenninger W, Hageman W, Arrindell W. Cross-national validity of dimensions of family functioning: first experiences with the Dutch version of the McMaster Family Assessment Device (FAD). Pers Indiv Differ. 1993;14:769-81.

7. Saeki T, Asukai N, Miyake Y, Miguchi M, Yamawaki S. Characteristics of family functioning in patients with endogenous monopolar depression. Hiroshima. J Med Sci. 2002;51(2):55-62.

8. Shek DTL. Assessment of Family Functioning in Chinese Adolescents: The Chinese Version of the Family Assessment Device. Res Social Work Prac. 2002;2:502-24. 
9. Diareme S, Tsiantis J, Kolaitis G, Ferentinos S, Tsalamanios E, Paliokosta E, et al. Emotional and behavioural difficulties in children of parents with multiple sclerosis: a controlled study in Greece. Eur Child Adolesc Psychiatry. 2006;15:309-18.

10. Kazarian SS. Cultural appropriateness of the Family Assessment Device (FAD) in the case of ethnic Armenian adolescents in Lebanon. Int I Soc Psychiatry. 2010;56:230-8.

11. Speranza M, Guenole F, Revah-Levy A, Egler PJ, Negadi F, Falissard B, et al. The French version of the Family Assessment Device. Can J Psychiatry. 2012;57:570-7.

12. Byles J, Byrne C, Boyle MH, Offord DR. Ontario Child Health Study: reliability and validity of the general functioning subscale of the McMaster Family Assessment Device. Fam Process. 1988;27:97-104

13. Keitner GI, Fodor J, Ryan CE, Miller IW, Bishop DS, Epstein NB. A cross-cultural study of major depression and family functioning. Can J Psychiatry. 1991;36:254-9.

14. Sawyer MG, Sarris A, Baghurst PA, Cross DG, Kalucy RS. Family Assessment Device: reports from mothers, fathers, and adolescents in community and clinic families. J Marital Fam Ther. 1988;14:287-96.

15. Al-Krenawi A, Graham JR, Slonim-Nevo V. Mental health aspects of Arab-Israeli adolescents from polygamous versus monogamous families. J Soc Psychol. 2002;142:446-60.

16. Kilic EZ, Ozguven HD, Sayil I. The psychological effects of parental mental health on children experiencing disaster: the experience of Bolu earthquake in Turkey. Fam Process. 2003;42:485-95.
17. Kazarian SS. Family functioning, cultural orientation, and psychological well-being among university students in Lebanon. J Soc Psychol. 2005;145:141-52.

18. Al-Krenawi A, Lev-Wiesel $R$, Sehwail MA. Psychological symptomatology among Palestinian male and female adolescents living under political violence 2004-2005. Community Ment Health J. 2007;43:49-56.

19. Beaton DE, Bombardier C, Guillemin F, Ferraz MB. Guidelines for the process of crosscultural adaptation of self-report measures. Spine (Phila Pa 1976). 2000;25:3186-91.

20. Wild D, Grove A, Martin M, Eremenco S, McElroy S, Verjee-Lorenz A, et al. Principles of Good Practice for the Translation and Cultural Adaptation Process for Patient-Reported Outcomes (PRO) Measures: report of the ISPOR Task Force for Translation and Cultural Adaptation. Value Health. 2005;8:94-104.

21. Bland JM, Altman DG. Statistical methods for assessing agreement between two methods of clinical measurement. Lancet. 1986;1:307-10.

22. Walrath CM, Franco E, Liao Q, Holden EW. Measures of Child Emotional and Behavioral Strengths and Family Functioning: A Preliminary Report on the Reliability and Validity of their Spanish translations. J Psychoed Assess. 2004;22:209-19.

23. Aarons $G A$, McDonald EJ, Connelly CD, Newton RR. Assessment of family functioning in Caucasian and Hispanic Americans: reliability, validity, and factor structure of the Family Assessment Device. Fam Process. 2007;46:557-69. 